PAWE⿺ BONAR

Uniwersytet Pedagogiczny, Kraków

\title{
Funkcjonowanie korporacji Ericsson w warunkach globalnego kryzysu gospodarczego
}

Postępujący proces rozwoju społecznego, gospodarczego i kulturowego wpływa na zmianę dotychczasowej bazy ekonomicznej i prowadzi do nowej fazy rozwoju cywilizacyjnego, odznaczającej się kreowaniem społeczeństwa informacyjnego. Dokonuje się on w wyniku pojawiania się nowych osiągnięć technologicznych i technicznych, które prezentują nowe podmioty gospodarcze związane z przemysłem IT. Wykorzystanie jego nowych możliwości zmienia często dotychczasowe metody produkcji, organizacji i zarządzania oraz gromadzenia i przetwarzania dużej ilości informacji oraz wpływa na budowanie gospodarki opartej na wiedzy (Zioło 2009).

Wpływ wiodących korporacji informatycznych i teleinformatycznych na kreowanie społeczeństwa informacyjnego oraz budowanie gospodarki opartej na wiedzy skłania do przeprowadzenia analizy procesu kształtowania się jednego ze wspomnianych podmiotów.

W świetle przedstawionych przesłanek przedmiotem niniejszych rozważań jest analiza działalności korporacji telekomunikacyjnej i teleinformatycznej Ericsson (Telefonaktiebolaget L.M. Ericsson). Jej celem jest przedstawienie procesów kształtowania się i organizacji przestrzennej ponadnarodowej korporacji Ericsson w warunkach globalnego kryzysu gospodarczego.

\section{ZARYS KSZTAŁTOWANIA SIĘ KORPORACJI ERICSSON}

Początki firmy sięgają roku 1876, kiedy to Lars Magnus Ericsson otworzył warsztat naprawy sprzętu telegraficznego. Wkrótce, gdy okazało się, że niezbędne są ulepszenia w produkowanych wówczas telefonach, rozpoczął własną produkcję. Na rynek trafił pierwszy wyprodukowany przez firmę Ericsson instrument telefoniczny (tak wówczas nazywano aparaty). Był to rok 1879, a 7 marca 1877 r. Aleksander Graham Bell otrzymał patent na zgłoszone rok wcześniej urządzenie nazwane telefonem. W roku 1887 w Sztokholmie odbyło się otwarcie największej na świecie centrali telefonicznej. Składała się ona z 24 łącznic mogących obsłużyć 7000 abonentów. W kolejnych latach firma Ericsson rozwijała swoją działalność na całym świecie, m.in. w Polsce, Rosji, Francji, Austrii, Wielkiej Brytanii, USA i Meksyku. W roku 1923 Ericsson wprowadził na rynek tarczę wybiórczą. W roku 1932 został zaprezentowany 
pierwszy aparat telefoniczny firmy Ericsson w obudowie z tworzywa sztucznego. W roku 1956 został wyprodukowany sześciomilionowy aparat telefoniczny jednoczęściowy Ericofon. W tym samym roku szwedzka firma zaprezentowała pierwszy prototyp telefonu komórkowego. Telefon ważył 40 kilogramów, a kształtem przypominał walizkę.

W roku 1961 LM Ericsson zawarł z Radą ds. Telekomunikacji umowę o współpracy badawczo-rozwojowej w dziedzinie elektroniki. W tym samym roku do automatycznych prywatnych i publicznych central telefonicznych został wprowadzony nowy rodzaj łącznika - łącznik kodowy, a w 1966 r. rozpoczęto produkcję telefonu Dialog z klawiaturą wybiórczą. Ericsson w roku 1971 dostarczył pierwszą na świecie centralę telefoniczną sterowaną komputerowo, służącą do obsługi automatycznego abonenckiego ruchu międzynarodowego i zamiejscowego. Nadto w latach siedemdziesiątych firma prowadziła już zaawansowane prace badawcze w dziedzinie wideotelefonii. W roku 1987 zaprezentowano prototyp pierwszego telefonu komórkowego HotLine Combi 450. Dwa lata później rozpoczęto seryjną produkcję udoskonalanego modelu HotLine Pocket, przypominającego dzisiejsze telefony komórkowe. Do roku 1995 systemy telefonii ruchomej firmy Ericsson, działające zgodnie ze wszystkimi ugruntowanymi normami przyjętymi na świecie, obsługiwały 34 miliony abonentów w 74 krajach.

Wzrost potencjału ekonomicznego światowych korporacji oraz nasilające się między nimi powiązania sieciowe w przestrzeni światowej (np. produkcyjne, naukowo-techniczne, organizacyjno-decyzyjne, finansowo-kapitałowe, zaopatrzenia surowcowego, kooperacyjne, a także powiązania rynkowe, energetyczne) oraz fuzje i przejęcia, generują procesy globalizacji i nasilają związane z nimi procesy integracji europejskiej (Zioło 2009).

Do października 2001 r. firma Ericsson była wiodącym producentem telefonów komórkowych. Pod koniec 2001 powstała firma Sony Ericsson - wspólne przedsięwzięcie firm Sony Corporation i Telefonaktiebolaget LM Ericsson z równo rozłożonymi udziałami. Połączone działy produkcji telefonów komórkowych od tego czasu produkują telefony marki Sony Ericsson. Celem obu korporacji było stworzenie nowej, silnej, atrakcyjnej globalnej marki wśród producentów aparatów komórkowych.

Dzięki aliansowi z firmami Redback i Tandberg Television (od 29 stycznia Ericsson Television) Ericsson stał się wiodącym producentem systemów do realizacji usług IPTV. Dziś firma może pochwalić się pełnym rozwiązaniem dla IPTV, które pozwala operatorom na wdrożenie urozmaiconych, interaktywnych i spersonalizowanych usług telewizyjnych. Oferuje ponadto rozwiązania najwyższej jakości w zakresie telewizji cyfrowej w standardzie High Definition (HDTV).

W roku 2009 w wyniku połączenia oddziału produkcji półprzewodników bezprzewodowych STMicroelectronics z oddziałem platform mobilnych Ericssona powstała druga po Sony Ericsson spółka joint venture z udziałami 50/50. Firma działająca pod nazwą ST-Ericsson jest jednostką zapewniającą unikatowe rozwiązania dla najnowocześniejszych przenośnych multimediów, łączności i platform, w tym projektów referencyjnych dla GSM, EDGE, WCDMA, HSPA oraz TD-SCDMA i LTE. ST-Ericsson posiada trwałe relacje ze wszystkimi głównymi producentami telefonów i jest czołowym dostawcą dla firm Nokia, Samsung, Sony Ericsson, LG i Sharp oraz dla innych liderów w tym sektorze.

Dnia 29 czerwca 2010 r. doszło do przejęcia udziałów konkurencyjnej firmy Nortel z Kanady w spółce joint venture LG - Nortel. Firma ta została założona w listopadzie 2005, zajmuje się sprzedażą sprzętu telekomunikacyjnego, central abonenckich i telefonów IP. Kanadyjski Nortel zapłacił w roku 2005145 mln USD za udziały 50\% plus 1. Ericsson 
w roku 2010 zapłacił ogłaszającemu upadłość Nortelowi $242 \mathrm{mln}$ USD, następnie firma zmieniła nazwę na LG - Ericsson umacniając pozycję lidera branży.

\section{ZARYS DZIAŁALNOŚCI KORPORACJI ERICSSON}

Korporacja Ericsson to największy na świecie dostawca technologii i usług dla operatorów telekomunikacyjnych, jest liderem w dziedzinie technologii mobilnych 2G, 3G i 4G i obsługuje sieci, z których korzysta ponad miliard abonentów. Zajmuje również czołową pozycję na rynku usług zarządzanych. W skład produktów firmy wchodzą: infrastruktura sieci stałych i mobilnych, Internet szerokopasmowy oraz rozwiązania multimedialne dla operatorów, firm oraz instytucji.

W ramach oferty dla operatorów sieci stacjonarnych i mobilnych znajdują się projektowanie, budowa oraz bieżące zarządzania siecią klienta, włączając w to usługi dla użytkownika końcowego, systemy wsparcia dla biznesu do zapewniania pokrycia sieci oraz zwiększanie przepustowości sieci na żądanie.

Standardową usługą oferowaną dla przedsiębiorstw są usługi zarządzające. Ericsson zobowiązuje się zarządzać sieciami klienta oraz dostarczać dla nich nowe rozwiązania. Od 2002 r. zawarł oficjalnie ponad 100 umów na usługi zarządzające z operatorami na całym świecie. W ramach wszystkich obowiązujących obecnie kontraktów tego typu, nie licząc hostingu, Ericsson zarządza sieciami, które łącznie obsługują ponad $350 \mathrm{mln}$ abonentów na całym świecie.

Ericsson zaopatruje w infrastrukturę i swoje rozwiązania instytucje sektora publicznego. Oferta firmy obejmuje budowę sieci bezpiecznych i wydajnych. Sieci dla sektora publicznego charakteryzuja się zaawansowanym systemem weryfikacji dostępu do nich. Z usług świadczonych dla sektora publicznego moga korzystać takie instytucje, jak wojsko, policja, służby ratownictwa medycznego, straż pożarna oraz straż graniczna.

W ramach oferty dla developerów Ericsson zobowiązuje się do zbudowania własnych lub modernizację istniejących instalacji wewnątrz budynkowych. Ericsson wprowadził też na rynek innowacyjne radiowe stacje bazowe (służące do rozsyłania sygnału dla komórek, Internetu bezprzewodowego oraz sygnału TV). Nowe rozwiązanie firmy Ericsson Capsule Site lub Tower Tube to innowacyjna konstrukcja budowlana, w której może zostać zainstalowana radiowa stacja bazowa.

Ericsson regularnie inwestuje w badania i rozwój nowych technologii. Wg raportu finansowego z roku 2009 prawie jedna trzecia (19 tys.) pracowników jest zatrudniona w tym obszarze działalności, natomiast na badania w roku 2009 firma przeznaczyła 13,1\% ze sprzedaży netto, tj. ponad 3,8 mld USD. Do tej pory Ericsson zarejestrował 25 tys. patentów. Największym obecnie osiagnięciem naukowców firmy Ericsson jest opracowana wspólnie z innymi gigantami telekomunikacyjnymi nowa technologia przesyłu danych, jaką jest LTE (Long Term Evolution). Pozwoli ona na transmisję danych z prędkością ponad $100 \mathrm{Mb} / \mathrm{s}$, a nawet $300 \mathrm{Mb} / \mathrm{s}$. Nowy standard popierają najwięksi światowi operatorzy. 


\section{WIELOMIERNIKOWA ANALIZA DYNAMIKI POTENCJAŁU EKONOMICZNEGO KORPORACJI ERICSSON}

W procesie kształtowania korporacji światowych ważnym problemem jest wielomiernikowa analiza dynamiki jej potencjału ekonomicznego. Proces funkcjonowania korporacji w warunkach kryzysu gospodarczego rozpatrzony zostanie w oparciu o takie mierniki, jak wartość przychodów ze sprzedaży, wartość aktywów, wartość kapitału własnego, wartość zysków oraz liczba pracujących.

Przychody ze sprzedaży to kwota uzyskana lub należna od odbiorcy z tytułu dokonanej sprzedaży składników aktywów jednostki oraz z tytułu świadczonych usług (Nowak 2008, s. 117). Jako przychody ze sprzedaży traktowano w pracy pozycję Net Sales, są to przychody ze sprzedaży netto, tzn. skorygowane o przewidywane zwroty sprzedanych produktów i towarów, udzielone rabaty oraz podatki, które zawarte są w wartości przychodów brutto.

W latach 1970-2009 wartość przychodu netto, czyli przychodów skorygowanych o przewidywane zwroty sprzedanych produktów i towarów, udzielone rabaty oraz podatki, wahały się w przedziale od 656,87 mln USD w roku 1970 do 33 110,11 mln USD w roku 1999, średni przychód wynosił 11 609,31 mln USD (tab. 1, ryc. 1).

Biorąc pod uwagę dynamikę wartości przychodu ze sprzedaży netto wyróżniono charakteryzujące się różnymi tendencjami okresy. W latach 1970-2009 wartość przychodu ze sprzedaży netto wzrosła z 656,8 mln USD do 29 mld w 2009, tj. ponad 59-krotnie.

Pierwszy okres odznaczający się nierównym, ale wyraźnym trendem rosnącym obejmuje lata 1970-1999, w tym czasie wartość sprzedaży wzrosła z 656,8 mln USD do 33,11 mld USD, tj. ponad 50-krotnie. Kolejny okres obejmujący lata 2000-2003 wykazywał tendencje spadkowe, wartość przychodu ze sprzedaży netto spadła z 29,86 mld USD w 2000 r. do 14,56 w roku 2003, tj. ponad 2-krotnie. Było to związane z ogólnym kryzysem branży informatycznej, którego przyczyn należy upatrywać z pompowaniem tzw. bańki internetowej i jej „pęknięciu” w roku 2001 i konsekwencjach w kolejnych latach. We wrześniu 2001 r. wartość rynkowa firm telekomunikacyjnych i dostawców spadła z rekordowego $6300 \mathrm{mld}$ USD zanotowanych w marcu roku 2000 do 3800 mld USD, czyli prawie 2-krotnie. W celu walki z kryzysem korporacja zmuszona była do redukcji zatrudnienia i emisji dodatkowych akcji o wartości 3 mld USD (Annual Report 2001).

Po roku 2003 w przedsiębiorstwie zaobserwowano pozytywne efekty walki z kryzysem. W latach 2004-2008 znów zaobserwowano tendencje wzrostowe, wartość sprzedaży wzrosła z 17,958 mld USD do 31,748 mld USD. W roku 2009 wartość przychodów ze sprzedaży netto spadła do 29,04 mld USD, przyczyn takiego zachowania miernika należy upatrywać w kryzysie ekonomicznym z lat 2007-2009. Pod koniec 2009 r. wartość przychodów ze sprzedaży netto spadła do 6,617 mld USD, tj. o 22,8\%. Wartości zamieszczone w sprawozdaniu finansowym z III kwartału $2010 \mathrm{r}$. wskazują na stopniową poprawę sytuacji wywołanej kryzysem gospodarczym. Wartość sprzedaży netto wzrosła z 6,617 mld USD z III kw. 2009 r. do 6,745 mld USD w III kw. 2010 r., tj. o 2\%. Są to najniższe wartości przychodów ze sprzedaży od roku 1989. Wyraźnie widać, iż firma Ericsson sprzedała znacznie mniej usług i produktów ze swojej oferty z powodu kryzysu. Przyczyn należy upatrywać w mniejszej liczbie zamówień oraz w trudnościach z zapewnieniem sobie komponentów do produkcji. 


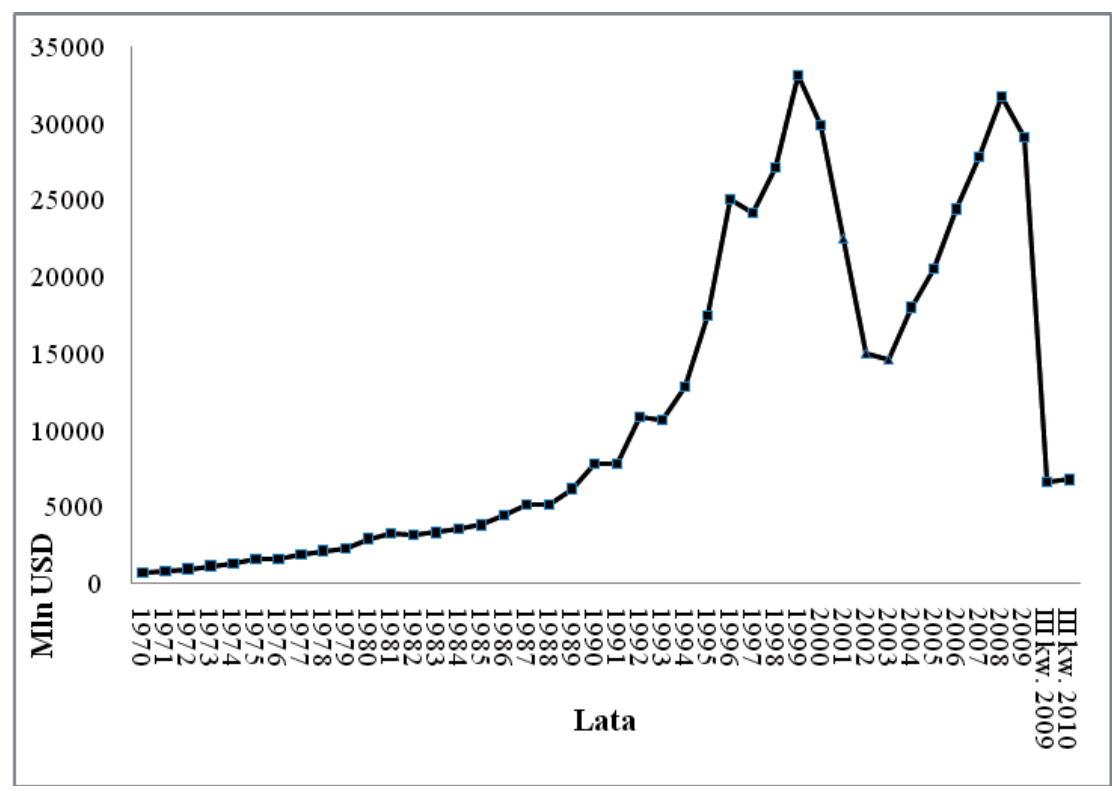

Ryc. 1. Zmiana wartości sprzedaży w latach 1970-2010

Źródło: opracowanie własne na podstawie tab. 1

Zysk w kontekście działalności gospodarczej to dochód uzyskany po wytworzeniu, wprowadzeniu na rynek i sprzedaży towaru po poniesieniu wszelkich kosztów (Munn i in. 1991, s. 837).

Wartość zysku w latach 1970-2009 wahała się od 31,1 mln USD w 1971 do 3582,94 mln USD w roku 2006. W latach 1970-2009 wartość zysku netto zwiększyła się z 42,099 mln USD do 580,450 mln USD, tj. prawie 14-krotnie (tab. 1, ryc. 2). Zważywszy na dynamikę, wyróżniono kilka okresów wykazujących różne tendencje. Pierwszy okres obejmujący lata 1970-1987 odznaczał się małymi wahaniami wartości zysku z 42,099 mln USD do 79,03 mln USD, można zatem przyjąć, iż był to okres stagnacji. Kolejny okres, lata 1988-1990, odznaczał się wyrównanym tempem wzrostu wartości z 115,923 mln USD w roku 1988 do 582,888 mln USD w 1990 r. Kolejne dwa lata wykazywały tendencje spadkowe wartości dochodu z 146,506 mln USD w roku 1991 do 82,076 mln USD w roku 1992. Od roku 1993 do 2000 zaobserwowano nierówny trend rosnący, wartość zysku wzrosła z 364,236 mln USD do 2,293 mld USD. W latach 2001-2003 przedsiębiorstwo poniosło straty, w rekordowym 2001 r. odnotowano na minusie 2,058 mld USD, rok później wartość straty wynosiła 1,952 mld USD, a w roku 2003 1,341 mld USD. W roku 2004 firma wyszła z kryzysu, jej działalność przynosiła zyski 2,427 mld USD. W latach 2005-2006 wartość zysku stopniowo rosła z 3,273 mld USD w 2005 do rekordowej w badanym okresie wartości wynoszącej 3,582 mld USD. Od roku 2007 do 2009 wartość zysku wykazywała tendencje spadkowe związane ze skutkami globalnego kryzysu, wartość zmniejszyła się z 3,274 mld USD w 2007 r. do 580,450 mln USD w roku 2009. W III kwartale 2009 r. wartość zysku spadła do 114,08 mln USD, była to najniższa wartość zysku osiagniętego przez firmę Ericsson od roku 2004. Dane z III kwartału 2010 roku wskazują na unormowanie sytuacji w korporacji. Działalność firmy przyniosła zyski w wysokości 511,2 mln USD, wygenerowano ponad 440\% wartości 


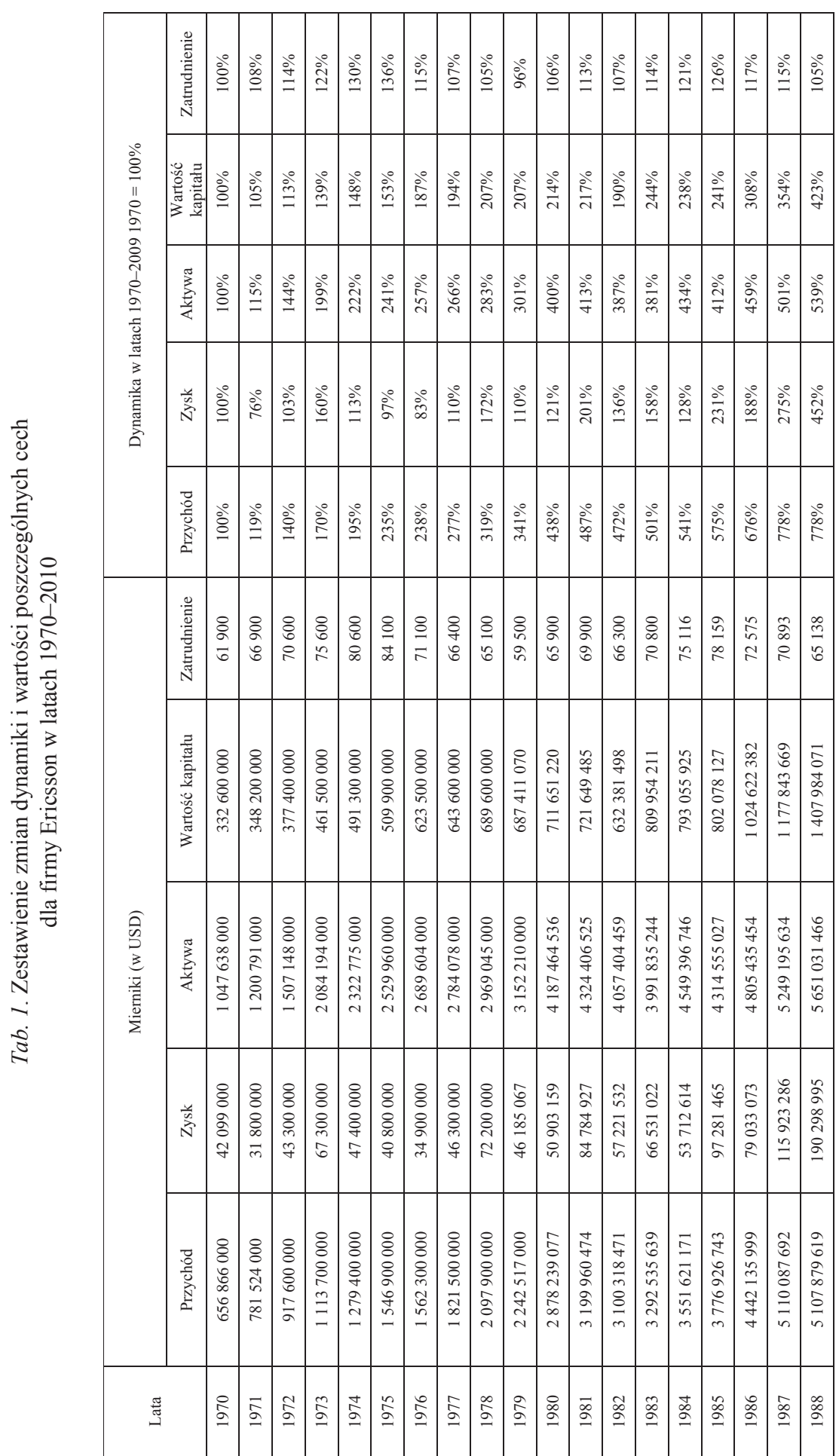




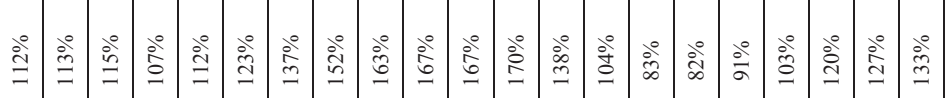

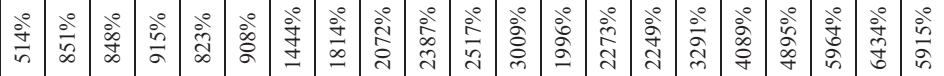

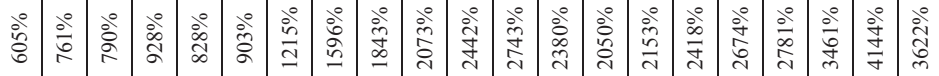

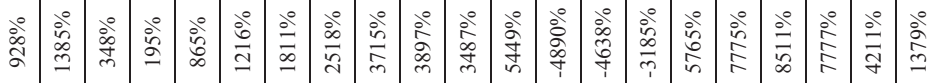

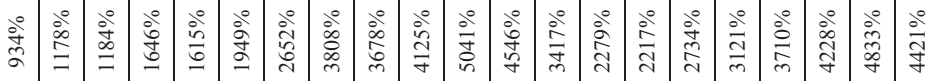

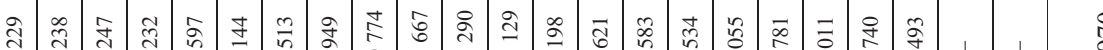

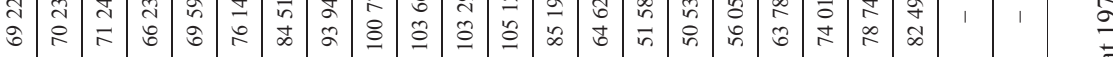

वे

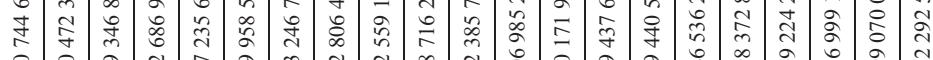

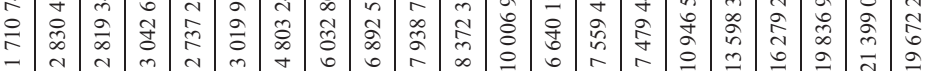

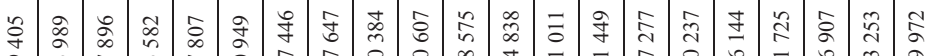

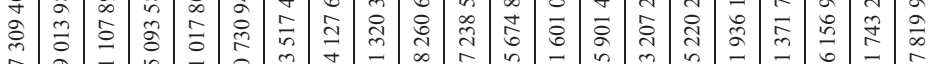

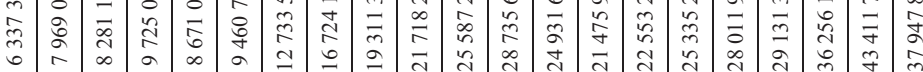

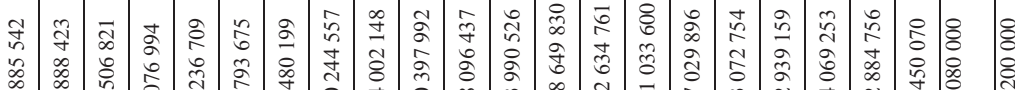

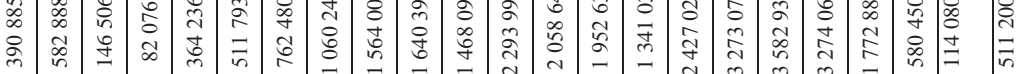

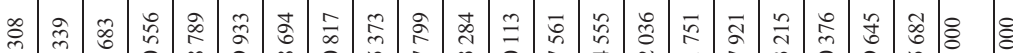

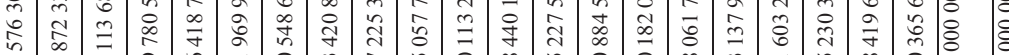

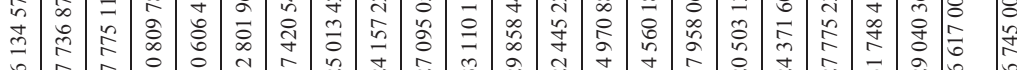

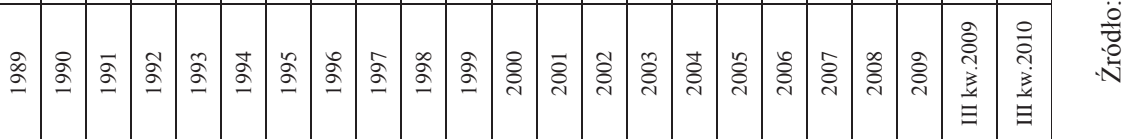


z poprzedniego roku. Tak dobre wyniki związane były z obniżeniem w tym okresie kosztów restrukturyzacji, jakie musiała ponieść firma oraz z poprawą sprzedaży w dziale sieciowym (wschodnie kontrakty).

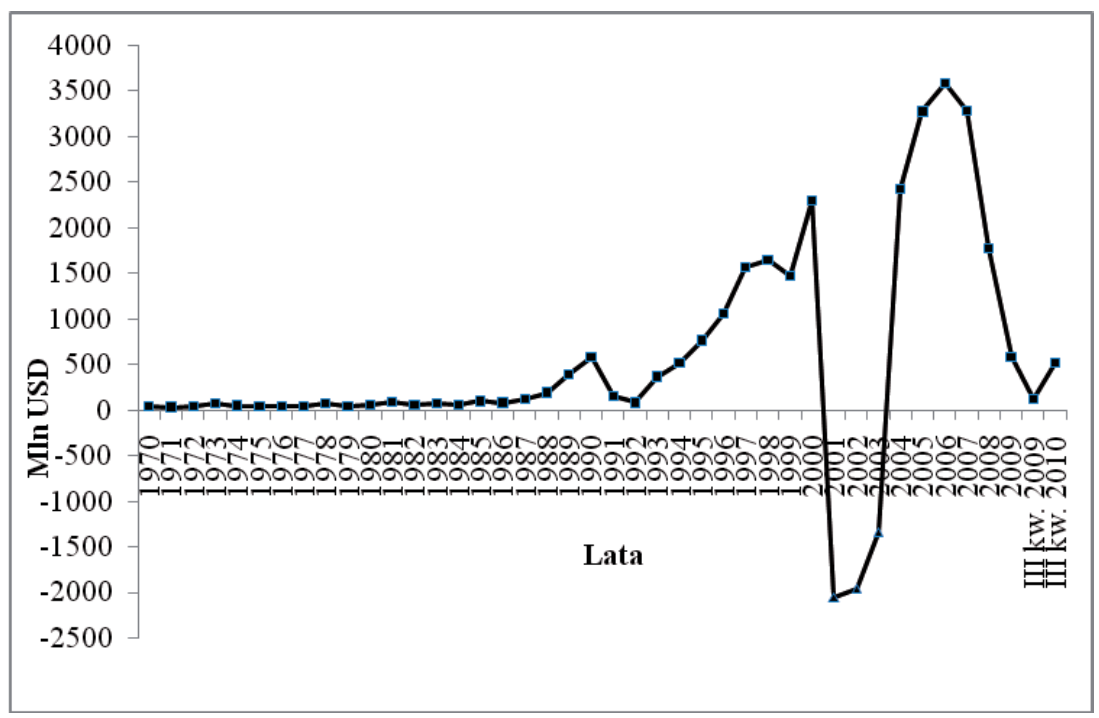

Ryc. 2. Zmiana wartości zysku/straty netto w latach 1970-2010

Źródło: opracowanie własne na podstawie tab. 1

Aktywa (assets) to zasoby kontrolowane przez jednostkę powstałe w wyniku zdarzeń z przeszłości, z których według przewidywań jednostka osiagnie w przyszłości korzyści ekonomiczne (Międzynarodowe Standardy Sprawozdawczości Finansowej 2004, s. 68). Wartościom aktywów odpowiadają wartości „wszystkich aktywów” (assets total) w sprawozdaniu finansowym korporacji Ericsson.

Wartość aktywów ogółem w latach 1970-2009 oscylowała w przedziale od $1048 \mathrm{mln}$ USD do 43412 mln USD, średnia wartość majątku w tym czasie wynosiła $12693 \mathrm{mln}$ USD.

W latach 1970-2009 wartość aktywów zwiększyła się z 1,047 mld USD do 37,947 mld USD, tj. ponad 36-krotnie (tab. 1, ryc. 3). Ze względu na dynamikę wyróżniono charakteryzujące się różnymi tendencjami okresy. W pierwszym, obejmującym lata 1970-2000, zaobserwowano nierówny trend rosnący, wartości aktywów wzrosła z 1,047 mld USD w 1970 r. do 28,73 mld USD w roku 2000, tj. ponad 27-krotnie. W roku 1993 miało miejsce nieznaczne załamanie trendu. W roku 2001 wartość aktywów zmniejszyła się do 24,9 mld USD, tendencje spadkowe utrzymywały się do roku 2002, wartość spadła wtedy do 21,475 mld USD. Lata 2003-2008 charakteryzowały się wyrównanym tempem wzrostu wartości z 22,553 mld USD w 2003 r. do rekordowej wartości aktywów w badanym okresie, tj. do 43,411 mld USD w roku 2008. W roku 2009 odnotowano spadek wartości aktywów do 37,947 mld USD. 


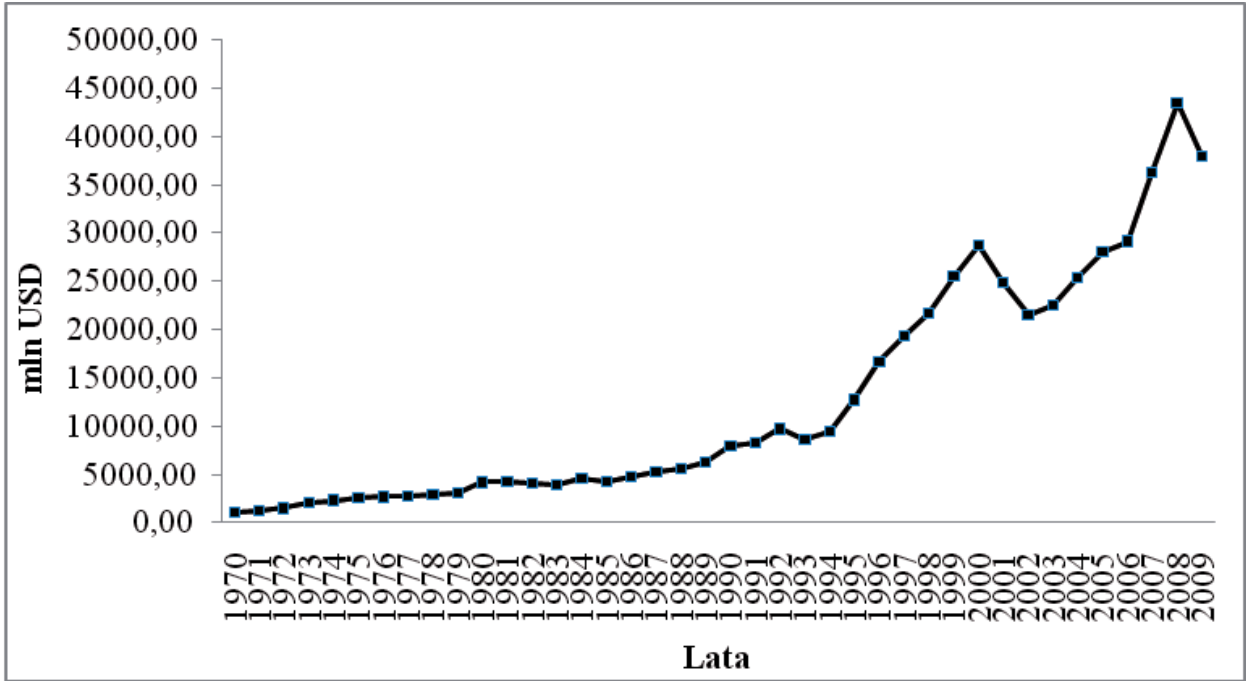

Ryc. 3. Zmiana wartości aktywów ogółem w latach 1970-2009

Źródło: opracowanie własne na podstawie tab. 1

Stockholders' equity to kapitał własny, czyli udział własny inwestorów w firmie. Jest to wartość środków gospodarczych wniesionych do firmy przez właścicieli (udziałowców, akcjonariuszy, wspólników) oraz środków wygospodarowanych przez przedsiębiorstwo w toku działalności.

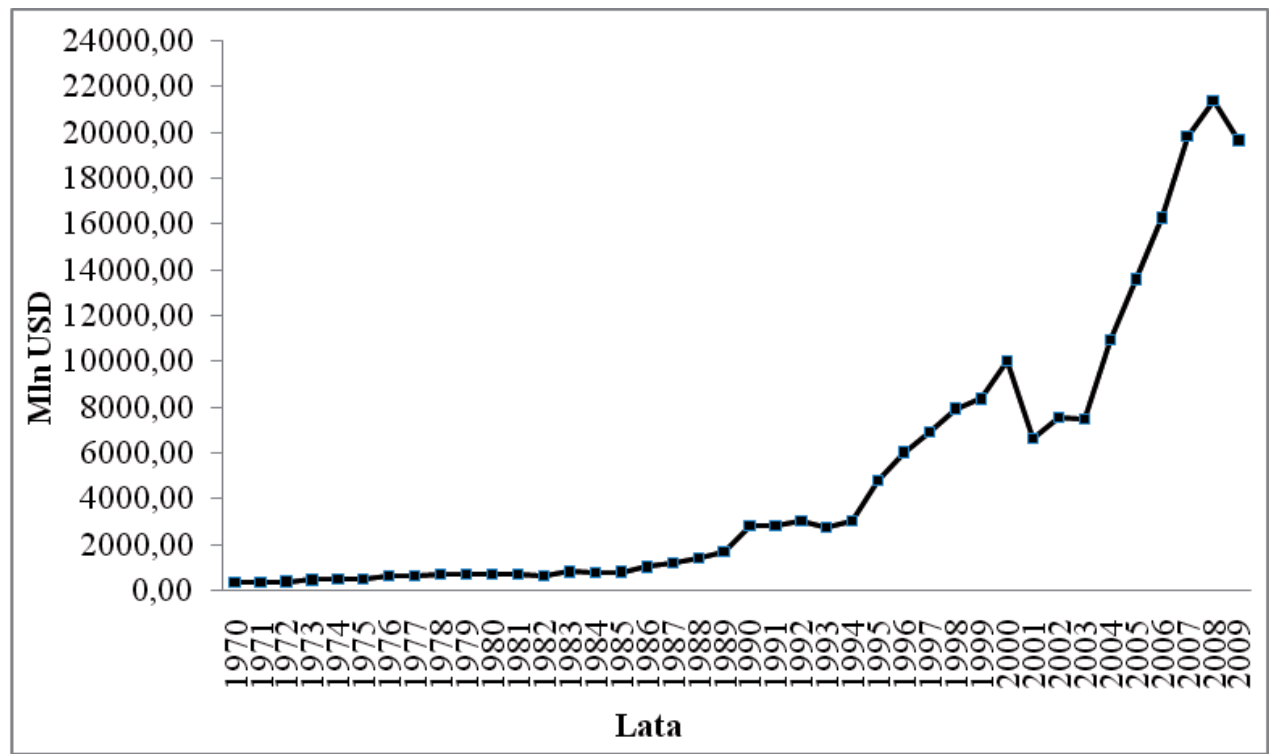

Ryc. 4. Zmiana wartości kapitału własnego w latach 1970-2009

Źródło: opracowanie własne na podstawie tab. 1 
W latach 1970-2009 wartość kapitału własnego zawierała się w przedziale od 332,6 mln USD w roku 1970 do 21399,1 mln USD w roku 2008, średnia wartość miernika wynosiła 4921,6 mln USD. W latach 1970-2009 wartość kapitału własnego wzrosła z 332,6 mln USD do 19,672 mld USD, tj. 59-krotnie (tab. 1 ryc. 4). W dynamice tej można wyróżnić klika okresów. Pierwszy, obejmujący lata 1970-1985, odznaczał się małymi wahaniami wartości, można zatem przyjąć, iż był to okres stagnacji. W latach 1986-1989 zaobserwowano tendencje wzrostowe, wartość kapitału wzrosła z 1,024 mld USD w roku 1986 do 1,710 mld USD w roku 1989, tj. do 167\%. W latach 1990-1994 wartość kapitału własnego ulegała niewielkim zmianom z 2,830 mld USD w 1990 roku do 3,019 mld USD w 1994 roku, można więc założyć, iż był to okres pewnej stagnacji. Okres obejmujący lata 19952000 odznaczał się dużym tempem wzrostu wartości kapitału z 4,803 mld USD w 1995 r. do 10,006 mld USD w 2000 r., tj. ponad 2-krotnie. W roku 2001 wartość kapitału własnego spadła do 6,64 mld USD. Lata 2002-2003 charakteryzowały się małymi wahaniami wartości kapitału, w roku 2002 wynosiła ona 7,559 mld USD, a w roku 2003 osiąnęła 7,479 mld USD, można zatem przyjąć, iż panowała wtedy stagnacja. Od roku 2004 do roku 2008 wartość kapitału wzrosła z 10,946 mld USD do 21,399 mld USD, tj. ponad 2-krotnie, jest to drugi okres tak dużego przyrostu wartości kapitału. W 2009 wartości kapitału spadła do 19,672 mld USD.

Średnia liczba zatrudnionych w latach 1970-2009 zwiększyła się z 61900 zatrudnionych w 1970 r. do 82493 zatrudnionych w 2009 r., tj. do 133\%. W dynamice tej można wyróżnić okresy. Pierwszy z nich obejmujący lata 1970-1975 charakteryzuje się wyrównanym tempem wzrostu zatrudnienia z 61900 osób do 84 100, tj. do 136\%. W latach 1976-1979 wartość zatrudnienia ogółem spadło z 71100 osób do 59500 osób, wartość miernika wykazywała tendencje spadkowe, można więc mówić o pewnej regresji. Od roku 1980 do 1981 liczba zatrudnionych wzrosła z 65900 do 69900 osób. W roku 1982 wartość zatrudnienia spadła do 66300 osób. W latach 1983-1985 liczba zatrudnionych wzrosła z 66300 do 78159 osób, wartość miernika wykazywała stałą tendencje wzrostową. W latach 19861988 zaobserwowano trend malejący, liczba zatrudnionych osób spadła z 72575 do 65138 . W latach 1989-1993 wartość miernika ulegała niewielkim wahaniom z 69229 osób w roku 1989 do 69597 osób w roku 1993, można zatem przyjąć, iż był to okres pewnej stagnacji. W latach 1994-2000 wartość miernika odznaczała się nierównym tempem wzrostu z 76144 osób w 1994 do 105129 zatrudnionych w roku 2000. W latach 2001-2004 zaobserwowano nierówny spadek liczby zatrudnionych z 85198 do 50534 osób. Od roku 2005 do roku 2009 nastąpił wyrównany przyrost wartości miernika od 56055 do 82493 osób.

\section{ANALIZA ROZMIESZCZENIA GŁÓWNYCH SIEDZIB}

\section{ORAZ REGIONALNYCH PRZEDSTAWICIELSTW KORPORACJI ERICSSON}

Korporacje transnarodowe, dążąc do poszerzania rynków działania, przenoszą lokalizacje swych oddziałów na tereny innych państw. W roku 2009 na całym świecie Ericsson zlokalizował 52 główne siedziby w 46 krajach, z czego 22 (tj. 42\%) znajduje się w Europie (ryc. 6,7). W Szwecji zlokalizowane jest 6 (tj. 11,5\%) głównych siedzib, w Azji 11 (21,2\%), w Ameryce Północnej 9 (17,3\%), a w Ameryce Południowej i Australii w sumie 4, co stanowi razem $7,6 \%$ ogółu filii. 
W raporcie finansowym korporacji Ericsson z roku 2009 wyróżniono dwa podstawowe typy oddziałów firmy. Pierwszy, do którego zaklasyfikowano 41 oddziałów firmy, obejmuje działalność produkcyjną, dystrybucję oraz działalność badawczo-rozwojową $(B+R)$. Natomiast 11 filii przyporządkowano do drugiego typu oddziałów zagranicznych stanowiących holdingi i oddziały finansowe.

Analizując zasięg oddziaływania korporacji ważne zagadnienie stanowi rozmieszczenie jej regionalnych przedstawicielstw.

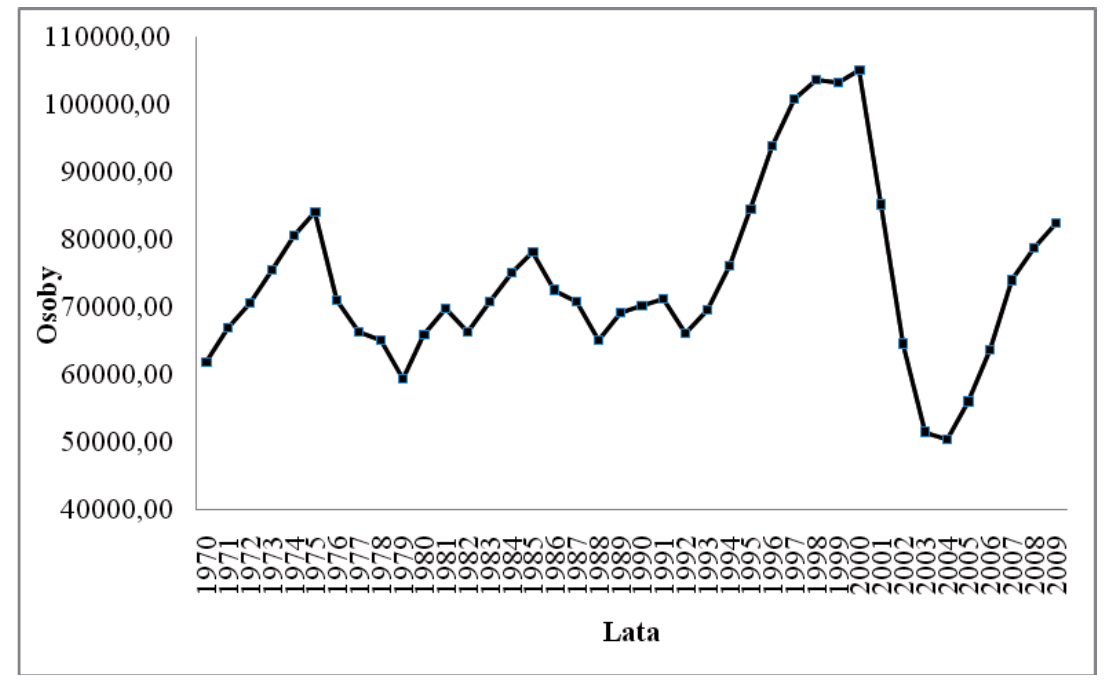

Ryc. 5. Zmiana wielkości zatrudnienia w latach 1970-2009

Źródło: opracowanie własne na podstawie tab. 1

W roku 2009 na całym świecie korporacja Ericsson posiadała 287 przedstawicielstw regionalnych w 121 krajach. Są to takie jednostki, jak biura sprzedaży, działy Human Resources oraz oddziały B + R. Najwyższą liczbą regionalnych przedstawicielstw cechuje się Azja z 132, tj. 46\% ogółu biur na świecie. W samych Chinach zlokalizowano 56, tj. 19,5\% ogółu przedstawicielstw na całym świecie. Kolejnym państwem z dużą liczbą biur zagranicznych są Indie, na terenie których mieści się 30, tj. 10,5\% ogółu przedstawicielstw na świecie. W Europie działa 87, tj. 30,3\% ogółu przedstawicielstw korporacji. Na terenie Szwecji Ericsson posiada 22 biura, co stanowi 7,7\% ogółu. Ericsson posiada swoje przedstawicielstwa w 42 krajach europejskich. W Polsce znajduje się jeden regionalny oddział z siedzibą w Warszawie. W Ameryce Północnej Ericsson posiada 27 (tj. 9,4\% ogółu) regionalnych przedstawicielstw, z czego 12 (4,2\% ogółu) jest zlokalizowanych na terenie Stanów Zjednoczonych. Na terenie pozostałych kontynentów znajduje się łącznie 41, tj. 14,3\% ogółu wszystkich regionalnych przedstawicielstw Ericssona na świecie, z czego 24 (tj. 8,4\%) znajdują się w Afryce.

Duża liczba przedstawicielstw w Azji świadczy o głównym kierunku ekspansji korporacji, jakim są wschodzące rynki, w szczególności Chiny i Indie. Wystarczy dodać, że w roku 2009 Ericsson podpisał umowy opiewające na 1,8 mld USD z chińskimi operatorami China Mobile i China Unicom. Nadto rynki wschodnie generują obecnie największe przychody. 


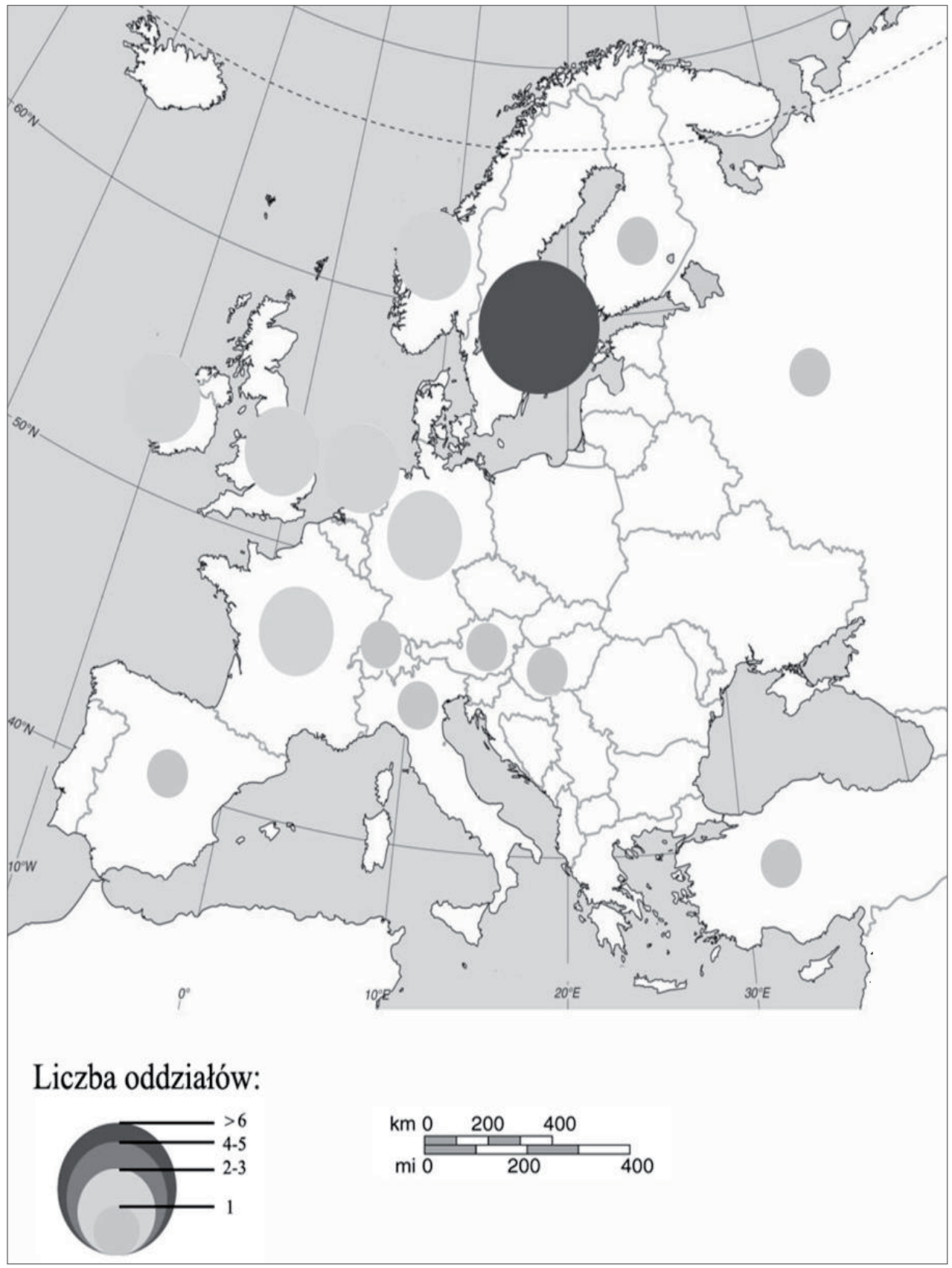

Ryc. 6. Lokalizacja siedzib Ericssona w Europie w roku 2009

Źródło: opracowanie własne na podstawie danych z raportu finansowego Ericssona z roku 2009 


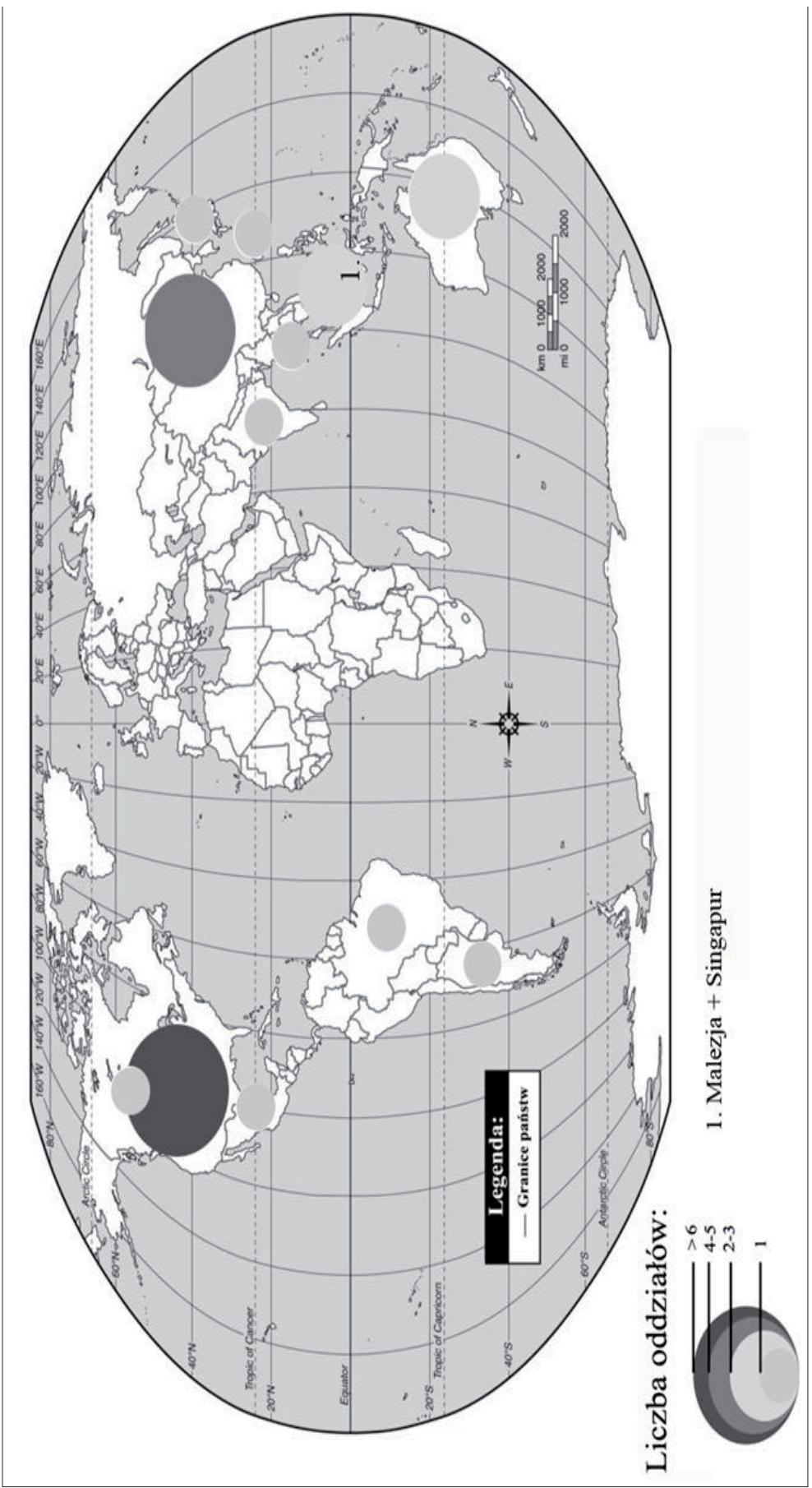

Ryc. 7. Lokalizacja siedzib Ericssona na Świecie w roku 2009

Źródło: opracowanie własne na podstawie danych z raportu finansowego Ericssona z roku 2009 
Chińskie firmy są największym klientem firmy Ericsson, generując 7\% przychodów spółki. Zaraz za nimi plasują się Indie, które pod względem przychodów są dla koncernu równie ważnym rynkiem jak USA. Na obu Ericsson realizuje po $6 \%$ swoich przychodów.

\section{WNIOSKI}

Pozycja lidera w technologii komunikacji przenośnej i stacjonarnej zapewnia firmie Ericsson silne podstawy przyszłego wzrostu. Pozycja ta jest ponaddwukrotnie silniejsza od pozycji najbliższego konkurenta. Obecnie niemal $40 \%$ połączeń wykonywanych przez telefony komórkowe na świecie zestawiane jest poprzez systemy dostarczone przez firmę Ericsson. Korporacja skutecznie realizuje swój długofalowy cel, jakim jest „stać się siłą napędową postępu w świecie komunikacji” poprzez innowacje, zaawansowane technologie oraz rozwiązania biznesowe zgodne z zasadami zrównoważonego rozwoju. Postępujący proces rozwoju technologii w zakresie telekomunikacji i łączności, a także opanowywanie coraz rozleglejszych rynków chińskich i indyjskich pozwoliło skutecznie przeciwdziałać negatywnym skutkom globalnego kryzysu gospodarczego oraz stwarza korzystne szanse dalszego rozwoju korporacji Ericsson.

\section{Literatura}

Bonar P., 2010, Kształtowanie się ponadnarodowej korporacji Ericsson (praca magisterska). Zakład Przedsiębiorczości i Gospodarki Przestrzennej, Instytut Geografii UP, Kraków.

Majewski J., 2005, Ericsson 100 lat w Polsce, Ericsson, Warszawa.

Międzynarodowe Standardy Sprawozdawczości Finansowej (MSSF), 2004, International Accounting Standard Bard, London, Stowarzyszenie Księgowych w Polsce, Warszawa.

Munn G.G., Garcia F.L., Woelfel Ch.J., 1991, Encyclopedia of Banking \& Finance, McGraw-Hill Book Company, London.

Nowak E., 2008, Analiza sprawozdań finansowych, PWE, Warszawa.

Zioło Z., 2006, Zróżnicowanie światowej przestrzeni przemystowej w świetle siedzib zarzq̨ów wiodacych korporacji, [w:] Międzynarodowe uwarunkowania rozwoju polskiego przemystu, red. Z. Zioło, T. Rachwał, Prace Komisji Geografii Przemysłu PTG, nr 8, Komisja Geografii Przemysłu PTG w Warszawie, IG AP w Krakowie, Warszawa-Kraków, s. 9-26.

Zioło Z.,2009, Struktura przestrzenna przemystu informatycznego w Polsce w 2007 roku, [w:] Problematyka XXV. Międzynarodowej Konferencji Naukowej nt. „Procesy transformacji przemystu i ustug w regionalnych i krajowych układach przestrzennych”, red. Z. Zioło i T. Rachwał, Warszawa-Kraków, s. 103-107.

Zioło Z., 2009, Procesy ksztaltowania się światowych korporacji i ich wplyw na otoczenie, [w:] Wpływ procesów globalizacji i integracji europejskiej na transformacje struktur przemysłowych, red.

Z. Zioło i T. Rachwał, Prace Komisji Geografii Przemysłu PTG, nr 12, Komisja Geografii Przemysłu PTG w Warszawie i IG AP w Krakowie, Warszawa-Kraków, s. 11-32.

http://www.ericsson.com/pl/

http://www.ericsson.com

http://www.ericssonhistory.com 


\section{Functioning of Ericsson company in the conditions of global economic crisis}

Ericsson is the company which has been operating on the market for more than thirty years. It continuously develops with the use of knowledge and innovations. The company was founded first as a workshop of telegraphic devices, and later became the leading provider of services for telecommunication companies. Ericsson is the leader in the field of mobile technologies 2G, 3G and $4 \mathrm{G}$, and it operates the networks used by more than billion subscribers.

The aim of the following thesis is to analyse the activity of Ericsson. Its aim is also to introduce the process of development and organization of Ericsson company internationally in the conditions of global economic crisis.

The expression of the development of this corporation is the increase in its economic potential between 1970 and 2009 and the increase of 29,04 billion USD in sales (from 656,86 billion USD), the worth of the assets from 0,5 billion USD to 37,95 billion USD, the worth of the profits from 42,09 billion USD to 580,45 billion USD, the worth of its own capital from 332,6 billion USD to 19,67 billion USD, and the increase in employment from 61,900 to 82,590 people.

Nowadays Ericsson company is operating in 185 countries and more than $95 \%$ of its sale takes place outside Sweden. At present Ericsson strengthens its position at eastern markets, mainly in China and India, which is proved by the big amount of regional representatives in both countries.

Chinese companies became the biggest customer of Ericsson company, generating $7 \%$ of the company's income. Next in line is India, which is as important as the USA, as far as the income is concerned. In both countries Ericsson gains $6 \%$ of its income.

The process of technological development in the fields of telecommunication and communication, as well as gaining bigger Chinese and Indian markets, allows to prevent the negative effects of global economic crisis and creates the chances for the further development of Ericsson company.

\section{Mgr Paweł Bonar}

Uniwersytet Pedagogiczny, Kraków

Instytut Geografii

Zakład Przedsiębiorczości i Gospodarki Przestrzennej

e-mail: pbonar@o2.pl 